\title{
Determination of plasma oxalate with oxalate oxidase
}

\author{
P. Boer ${ }^{a}{ }^{a}$, L. van Leersum ${ }^{a}$ and H.J. Endeman ${ }^{b}$ \\ ${ }^{a}$ Department of Nephrology and Hypertension and ${ }^{b}$ Department of Clinical Chemistry, University Hospital, \\ Utrecht (The Netherlands)
}

(Received June 22nd; revision August 23rd, 1983)

Key words: Plasma oxalate; Oxalate oxidase; Glyoxylate

\section{Summary}

A method for the determination of plasma oxalate using oxalate oxidase (EC 1.2.3.4) and deproteinised plasma is described. Reference values are 1.2-6.4 $\mu \mathrm{mol} / \mathrm{I}$ $(n=24$, mean $\pm \mathrm{SD} 3.3 \pm 1.5 \mu \mathrm{mol} / 1)$. The sensitivity is 6-7 nmol, the accuracy 3-5 $\mathrm{nmol}$, and the coefficient of variation $10.4 \%$ (at a level of $23 \mathrm{nmol}$ ). The recovery from plasma spiked with oxalate was $105 \pm 8 \%(n=8)$. Allowing blood to stand for $4 \mathrm{~h}$ at room temperature had no effect on plasma oxalate levels; inhibitors of glyoxylate converting enzymes interfered with oxalate oxidase.

\section{Introduction}

A large number of techniques for the determination of oxalate in plasma or serum have been published (Table I). For most of the in vitro methods [1-13], the reported normal reference values are rather high compared with those obtained with in vivo $\left[{ }^{14} \mathrm{C}\right]$ oxalate clearance methods [14-18]. Recently, however, two in vitro methods with a lower range of normal values were published $[12,13]$. The present report describes a third technique, making use of the enzyme oxalate oxidase. which has the advantage of liberating two $\mathrm{mol} \mathrm{CO}_{2}$ per mol oxalate. Because of the controversy about the in vitro generation of oxalate by glyoxylate converting enzymes and the need to use inhibitors of these enzymes [12,13], we investigated the influence of addition of inhibitors, and of delayed processing of the blood.

* Correspondence to P. Boer, Department of Nephrology and Hypertension, University Hospital, Catharijnesingel 101, 3511 GV Utrecht, The Netherlands. 
TABLE I

Reported normal reference values for plasma oxalate (in $\mu$ mol $/$ )

\begin{tabular}{lccccccl}
\hline Authors & Year & Ref. & Range & Mean & SD & $n$ & Technique \\
\hline Chambers and Russell & 1973 & 1 & - & 161 & 99 & 20 & GC \\
Yaoet al & 1975 & 2 & $33-111$ & - & - & - & Enz/Pot \\
Crawhall and Watts & 1961 & 3 & $<45$ & - & - & 22 & Enz/Gas \\
Hatch et al & 1977 & 4 & $8-52$ & 20.3 & 10.1 & 40 & Enz/Spect \\
Sugiura et al & 1980 & 5 & $7-46$ & - & - & 50 & Enz/Col \\
Gelot et al & 1980 & 6 & $9-41$ & 20.0 & 8.8 & 40 & GC \\
Zarembski and Hodgkinson & 1965 & 7 & $15-31$ & - & - & 15 & Fluor \\
Krugers et al & 1976 & 9 & $13-28$ & - & - & 20 & Col \\
Nuret and Offner & 1978 & 9 & - & 16.0 & 4.5 & 20 & GC \\
Knowles and Hodgkinson & 1972 & 10 & $9-16$ & 13.1 & 2.7 & 20 & Enz/Col \\
Bennett et al & 1979 & 11 & $5-17$ & 9.8 & 3.1 & 15 & Rad \\
Present study & 1983 & - & $1.2-6.4$ & 3.3 & 1.5 & 24 & Enz/Pot \\
Wolthers and Hayer & 1982 & 12 & $1.3-5.3$ & 2.8 & 1.1 & 22 & GC \\
Akcay and Rose & 1980 & 13 & $0-5.4$ & 2.3 & 1.7 & 20 & Enz/Pot \\
Williams et al & 1971 & 14 & $1.4-2.3$ & 2.0 & 0.6 & 6 & lsot \\
Pinto et al & 1974 & 15 & $0.4-2.8$ & 1.4 & 0.3 & 6 & Isot \\
Hodgkinson and Wilkinson & 1974 & 16 & $1.3-1.6$ & 1.4 & 0.2 & 3 & Isot \\
Prenen et al & 1982 & 17 & $1.0-1.8$ & 1.4 & 0.3 & 10 & lsot \\
Constable et al & 1974 & 18 & $0.8-2.1$ & 1.3 & 0.5 & 8 & Isot \\
\hline
\end{tabular}

Abbreviations: GC, gas chromatographic; Enz. enzymatic; Pot, potentiometric; Gas, gasometric; Fluor. fluorimetric; Spect, spectrophotometric; Col, colorimetric; Rad, radioenzymatic; Isot, in vivo isotope clearance.

\section{Materials and methods}

Reagents

All chemicals were purchased in p.a. grade from Merck AG (Darmstadt, FRG). Bovine liver catalase (EC 1.11.1.6, 65000 U/mg) was obtained from Serva GmbH (Heidelberg. FRG), diluted 1:9 $(130000 \mathrm{U} / \mathrm{ml})$, and stored in portions at $-20^{\circ} \mathrm{C}$. Oxalate oxidase (EC 1.2.3.4) was purified from barley seedlings by the method of Kohlbecker et al [19] and Chiriboga [20]. The final purification was done on a $2.6 \times 40 \mathrm{~cm}$ DEAE-Sepharose CL-6B column (Pharmacia, Uppsala, Sweden), and enzyme activity in the fractions was assessed with guajacol and peroxidase (EC 1.11.1.7) [21]. The final solution contained $6.4 \mathrm{U} / \mathrm{ml}$ oxalate oxidase. specific activity $22.2 \mathrm{U} / \mathrm{mg}$, and was stored in portions at $-20^{\circ} \mathrm{C}$.

The following solutions, which were prepared from $\mathrm{CO}_{2}$-free, $\mathrm{O}_{2}$-saturated deionised water, were used for the determinations; succinate buffer (freshly prepared): succinic acid $50 \mathrm{mmol} / \mathrm{l}$, EDTA di-sodium salt $5 \mathrm{mmol} / 1$, merthiolate 0.025 mmol $/ 1, \mathrm{pH}$ adjusted to 3.8 with $1 \mathrm{~mol} / 1 \mathrm{NaOH}$; alkaline buffer (stock solution): sodium carbonate $216 \mathrm{mmol} / \mathrm{l}$, sodium hydrogen carbonate $384 \mathrm{mmol} / 1$, diluted $1: 1000$ before use (final concentration $0.60 \mathrm{mmol} / 1, \mathrm{pH} \mathrm{9.8);} \mathrm{and} \mathrm{oxalate} \mathrm{standard}$ solution: oxalic acid dihydrate $1 \mathrm{mmol} / 1$.

For the enzyme inhibitor experiments, the following solutions were used: boric 
acid $700 \mathrm{mmol} / 1$, TRIS $420 \mathrm{mmol} / 1$, DL- $\beta$-phenyllactic acid $280 \mathrm{mmol} / 1$, sodium pyruvate $280 \mathrm{mmol} / 1$, potassium iodate $42 \mathrm{mmol} / 1$, and allopurinol $17.5 \mathrm{mmol} / 1$. 1 vol. of these solutions was combined with 6 vols. of succinate buffer before use.

\section{Equipment}

For the incubations, use was made of conical $50-\mathrm{ml}$ flasks provided with a B $19 / 26$ socket and a solid stopper, and with a $35 \times 10 \mathrm{~mm}$ inner cylinder mounted at the bottom. A Radiometer type PHM 62 (Copenhagen, Denmark) equipped with an Ingold type HA-405-M8 (Zürich, Switzerland) combined glass electrode was used for $\mathrm{pH}$ measurements. All manipulations were carried out in an Isolette model C-77 incubator (Hatboro, PA, USA).

\section{Procedures}

Preparation of blood samples. Fifty milliliters of heparinised blood was centrifuged for $10 \mathrm{~min}$ at $2000 \times \mathrm{g}$ and $4^{\circ} \mathrm{C}$ immediately after collection. Plasma was deproteinised [13] by adding an equal volume of $0.05 \mathrm{mmol} / 1 \mathrm{HCl}$ and heating in a waterbath at $100^{\circ} \mathrm{C}$ for $5 \mathrm{~min}$. After centrifugation for $30 \mathrm{~min}$ at $20000 \times \mathrm{g}$ and $4^{\circ} \mathrm{C}$, the supernatant was adjusted to $\mathrm{pH} 3.8$ with $1 \mathrm{mmol} / 1 \mathrm{HCl}$, merthiolate was added to a concentration of $0.025 \mathrm{mmol} / 1$, and the material was stored at $-20^{\circ} \mathrm{C}$. After storage for at least 6 months, there was no increase or decrease in the measured oxalate content. Addition of $\left[{ }^{14} \mathrm{C}\right]$ oxalate prior to deproteinisation resulted in a recovery of $98 \pm 2 \%(n=6)$ of the radioactive label in the supernatant. Because oxalate is not metabolised by plasma [22], this finding may be interpreted as a complete recovery of oxalate.

Determination of oxalate. Measurements in deproteinised plasma and corresponding blanks were performed in duplicate. The outer compartments of the flasks were filled with $10-15 \mathrm{ml}$ deproteinised plasma, the volume was made up to $20 \mathrm{ml}$ with succinate buffer, and $1300 \mathrm{U}$ catalase were added. Measurements of reagent blanks and standards were performed in triplicate: the outer compartments were filled with $20 \mathrm{ml}$ succinate buffer with or without addition of standard solution (100 nmol), followed by addition of catalase. The inner cylinders were provided with $1 \mathrm{ml}$ alkaline buffer and the reaction was started by addition of $0.25 \mathrm{U}$ of oxalate oxidase to all flasks except the plasma blanks. After incubation for $72 \mathrm{~h}$ at $20 \pm 1^{\circ} \mathrm{C}$, the $\mathrm{pH}$ of the alkaline buffer was measured. Shorter incubation times led to smaller $\mathrm{pH}$ decreases. The plasma oxalate concentrations $(\mathrm{nmol} / \mathrm{ml}$ or $\mu \mathrm{mol} / 1)$ were calculated using the formula:

$P_{\mathrm{Ox}}=\frac{(\mathrm{pH} \text { plasma blank }-\mathrm{pH} \text { deproteinised plasma })}{(\mathrm{ml} \text { deprot. plasma } / 2) \times(\mathrm{pH} \text { reagent blank }-\mathrm{pH} \text { standard }) / 100}$

\section{Results}

\section{Linearity}

As Fig. 1 shows, the relationship between $\mathrm{pH}$ and amounts of oxalate added to succinate buffer appeared to be linear up to at least $100 \mathrm{nmol}$. 


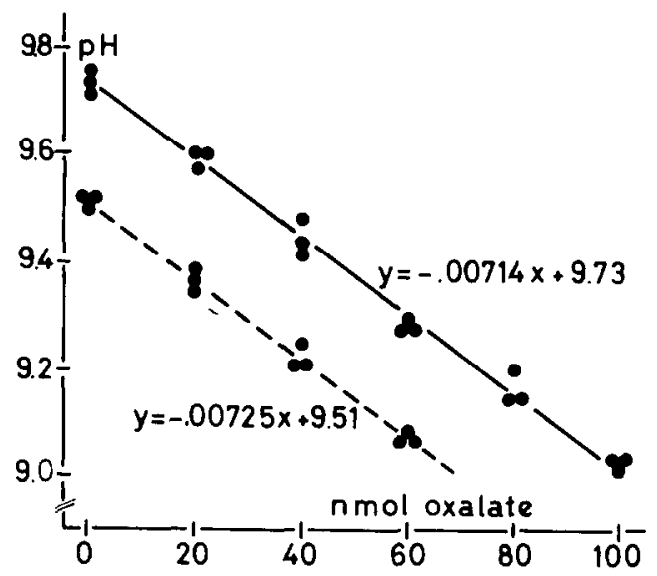

Fig. 1. Decrease in pH of alkaline buffer after addition of standard oxalate to succinate buffer (solid line) and deproteinised plasma (dashed line).

\section{Parallellism}

Fig. 1 also shows that the addition of oxalate to deproteinised plasma gave rise to a standard line with the same slope as that of the external standard line.

\section{Accuracy}

The values obtained in a large number of determinations were used to calculate the mean of the standard deviations for triplicate standards and reagent blanks $(n=47)$ and duplicate unknowns and plasma blanks $(n=98)$ (Table II). Comparison of the variances by Bartlett's homogeneity test points to heteroscedasticity $\left(x^{2}=15.2, \mathrm{df}=3, p<0.002\right)$. Calculation of the variance ratio, $F$, for reagent blanks and standards showed no significant difference; the same holds for the variance ratio of unknowns and plasma blanks. The $F$ ratio of the combined variance of reagent blanks plus standards and combined variance of unknowns plus plasma blanks reaches significance (Table II).

TABLE II

Variance ratios for standard deviations in reagent blanks, standards, unknowns and plasma blanks

\begin{tabular}{lllll}
\hline Samples & Mean SD & $F$ & $\mathrm{df}$ & $p$ \\
\hline Reagent blanks & 0.026 & & & \\
Standards & 0.024 & 1.17 & 46,46 & $>0.10$ \\
Combined & 0.025 & & & \\
Unknowns & 0.019 & & & $>0.10$ \\
Plasma blanks & 0.017 & 1.25 & 97,97 & $<0.001$ \\
Combined & 0.018 & 1.93 & 91,193 & \\
\hline
\end{tabular}

Abbreviations: SD, standard deviation (in pH-units); $F=$ variance ratio: df. degrees of freedom; $p$. significance. 
TABLE III

Recovery of standard oxalate after addition of $6.7 \mu \mathrm{mol} / \mathrm{A}$ to 5 plasma samples

\begin{tabular}{llcc}
\hline Plasma & \multicolumn{3}{l}{ Standard oxalate recovered $(\mu \mathrm{mol} / 1)$} \\
\cline { 2 - 4 } & control & expected & measured \\
\hline A & 2.1 & 8.8 & 8.6 \\
B & 2.3 & 9.0 & 9.4 \\
C & 3.4 & 10.1 & 11.1 \\
D & 3.7 & 10.4 & 11.4 \\
E & 3.8 & 10.5 & 9.9 \\
Mean & 3.1 & 9.8 & 10.1 \\
\hline
\end{tabular}

\section{Sensitivity}

If a pH decrement of $0.7-0.8 \mathrm{pH}$ units is assumed for the standard of $100 \mathrm{nmol}$ (see also Fig. 1) and $2 \times \mathrm{SD}=0.05$ for the reagent blank, calculation yields a sensitivity of $6-7 \mathrm{nmol}$.

\section{Precision}

Table III shows the results of addition of a known amount of oxalate to different plasmas, and Fig. 2 of addition of increasing amounts of oxalate to a single plasma. Overall, the mean recovery amounted to $105 \pm 8 \%(n=8)$.

\section{Reproducibility}

One plasma with a mean concentration of $7.7 \mu \mathrm{mol} / 1$ was analysed seven times over a 4-month period; for thcse determinations, $6 \mathrm{ml}$ of deproteinised plasma was used instead of 10-15 ml, which corresponds to an actual measured amount of $23.1 \pm 2.4 \mathrm{nmol}$ oxalate. At this level, the coefficient of variation was $10.4 \%$.

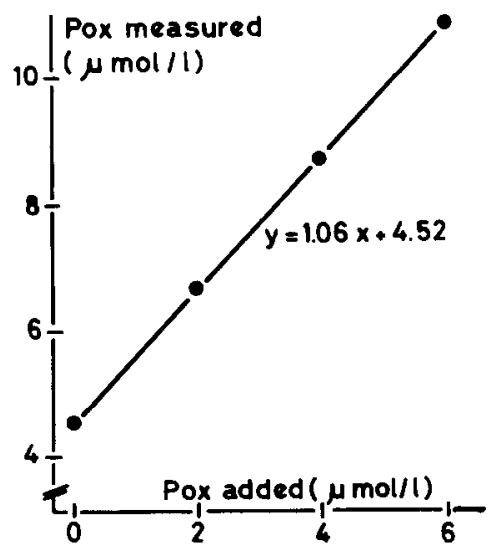

Fig. 2. Recovery of standard after addition to plasma in increasing amounts. 
TABLE IV

Effect of delayed processing of blood on plasma oxalate (in $\mu \mathrm{mol} / \mathrm{1})$

\begin{tabular}{|c|c|c|c|}
\hline \multirow[t]{2}{*}{ Plasma } & \multicolumn{3}{|l|}{ Time } \\
\hline & $\mathrm{Oh}$ & $2 \mathrm{~h}$ & $4 \mathrm{~h}$ \\
\hline$F$ & 3.7 & 4.0 & 3.7 \\
\hline $\mathrm{G}$ & 5.3 & 5.0 & 4.7 \\
\hline $\mathrm{H}$ & 5.5 & 5.5 & 5.0 \\
\hline 1 & 12.3 & 10.6 & 12.0 \\
\hline Mean & 6.6 & 6.6 & 6.4 \\
\hline
\end{tabular}

Time effects

The effect of delayed processing of samples was studied by dividing each of four samples of blood into three portions. One portion was used immediately, and the other two after standing at room temperature for 2 and $4 \mathrm{~h}$. The results (Table IV) show that plasma oxalate does not tend to decrease or increase significantly with time.

\section{Enzyme inhibitors}

The effect of inhibitors of xanthine oxidase (EC 1.2.3.2), lactate dehydrogenase (EC 1.1.1.27), and glycollate oxidase (EC 1.1.3.1) was assessed by adding these inhibitors to succinate buffer and measuring the changes in $\mathrm{pH}$ of the alkaline buffer in the presence and absence of oxalate oxidase in the incubation mixture. As Table $V$ shows, some of the inhibitors interfered with the determination: two of them served partially as a substrate for oxalate oxidase, which led to $\mathrm{CO}_{2}$ generation, and two others gave non-enzymatic $\mathrm{pH}$ dccrcases. This was also the case for a combination of the three least interfering inhibitors. On the basis of these findings, no attempt was made to evaluate the effect of the addition of inhibitors to whole blood.

\section{TABLE $V$}

Effect of enzyme inhibitors on pH of alkaline buffer

\begin{tabular}{lllll}
\hline $\begin{array}{l}\text { Enzyme to be } \\
\text { inhibited }\end{array}$ & Inhibitor & \multicolumn{2}{l}{$\begin{array}{l}\text { pH decrease with oxalate } \\
\text { oxidase }\end{array}$} & Effect * \\
\cline { 2 - 4 } & & absent & present \\
\hline Xanthine oxidase & Allopurinol & 0.00 & 0.16 & \pm \\
Lactate dehydrogenase & Borate & 0.67 & 0.60 & + \\
& Iodate & 0.00 & 0.00 & + \\
Glycollate oxidase & Pyruvate & 0.70 & 0.74 & + \\
& Phenyllactate & 0.06 & 0.54 & + \\
All 3 enzymes & TRIS & 0.00 & 0.00 & + \\
\hline
\end{tabular}

* + and - , interfering effect present or absent, respectively. 


\section{Reference values}

In a group of 24 apparently healthy fasting subjects ( 14 males, 10 females), the mean concentration of plasma oxalate was $3.3 \pm 1.5 \mu \mathrm{mol} / 1$ with a range of $1.2-6.4$ $\mu \mathrm{mol} / \mathrm{l}$.

\section{Discussion}

Plasma oxalate levels determined by the technique described here give normal values that are among the lowest reported in the literature for chemical methods. The method provides good linearity and parallelism, and the precision and reproducibility are adequate.

Although the accuracy was slightly lower for standards (mean SD of $0.025 \mathrm{pH}$ units) than for samples (mean SD of $0.018 \mathrm{pH}$ units), the $\mathrm{pH}$ decrease is generally smaller for samples than for standards, which makes the relative SD larger for samples than for standards. This in turn makes the SD for the actual measured amount of oxalate (see also the equation in 'Methods') almost independent of that amount, especially in the lower concentration range. For example, if a typical $\mathrm{pH}$ decrease of 0.75 is assumed for the standard (see Fig. 1) and 0.15 for a sample containing $20 \mathrm{nmol}$ oxalate (e.g. $10 \mathrm{ml}$ deproteinised plasma with a concentration of $4 \mu \mathrm{mol} / \mathrm{l}$ plasma), an SD of $\pm 3.5 \mathrm{nmol}$ is obtained (denominator $\pm 17 \%$, nominator $\pm 4.7 \%$ ), i.e. $\pm 0.7 \mu \mathrm{mol} / 1$. For samples containing $5,10,40$ and $80 \mathrm{nmol}$, the calculated values for the SD are 3.4, 3.4, 3.9 and $5.1 \mathrm{nmol}$, respectively.

The sensitivity depends mainly on the volume and strength of the alkaline buffer. In our hands, the use of $1.0 \mathrm{ml}$ buffer with a concentration of $0.06 \mathrm{mmol} / \mathrm{l}$ carbonate/bicarbonate gave optimal results. At a detection limit of 6-7 nmol, the use of $15 \mathrm{ml}$ deproteinised plasma permits the determination of plasma concentrations of $0.8-0.9 \mathrm{nmol} / \mathrm{l}$, which is below our range of normal reference values.

Akcay et al [13] have advocated the use of inhibitors for enzymes capable of oxidising glyoxylate, because blood can generate oxalate spontaneously on standing. As inhibitors, these authors used boric acid, DL- $\beta$-phenyllactic acid, and allopurinol, none of which interfered with their enzyme, i.e., oxalate decarboxylase (EC 4.1.1.2). However, these and other inhibitors gave substantial interference when the enzyme oxalate oxidase was used (Table V). Our experiment with delayed processing of blood samples shows that the need for the use of inhibitors is questionable, because plasma oxalate levels remained constant up to $4 \mathrm{~h}$ of standing at room temperature (Table IV). These findings are in agreement with those of Wolthers and Hayer [12], who studied the effect of standing time on serum.

Finally, some remarks must be made in this context on the use of electrodes. We have tested several makes of combined glass electrodes and found most of them to be unstable or to react too slowly in the higher $\mathrm{pH}$ range. Only the Ingold HA-405-M8 and the Russell TR-CMAWL-6-TB were suitable for our purposes. With this restriction, the method presented here is a convenient one, requiring only simple equipment. 


\section{Acknowledgement}

This study was supported by the Dutch Kidney Foundation.

\section{References}

1 Chambers MM, Russell JC. A specific assay for plasma oxalate. Clin Biochem 1973; 6: 22-28.

2 Yao SJ, Wolfson SK Jr, Tokarsky JM. Enzymatic-potentiometric determination of oxalic acid. Bioelectr Bioenerg 1975; 2: 348-350.

3 Crawhall JC, Watts RWE. The oxalate content of human plasma. Clin Sci 1961; 20: 357-366.

4 Hatch M. Bourke E, Costello J. New enzymic method for serum oxalate determination 1977; 1: $76-78$.

5 Sugiura M, Yamamura $H$, Hirano et al. Enzymic determination of serum oxalate. Clin Chim Acta 1980; $105: 393-399$.

6 Gelot MA, Lavoue G, Belleville F, Nabet P. Determination of oxalates in plasma and urine using gas chromatography. Clin Chim Acta 1980; 106: 279 285.

7 Zarembski PM. Hodgkinson A. The fluorimetric determination of oxalic acid in blood and other biological materials. Biochem J 1965; 96: 717-721.

8 Krugers Dagneaux PGLC, Klein Elhorst JT, Olthuis FMFG. Oxalic acid determination in plasma. Clin Chim Acta 1976: 71: 319-325.

9 Nuret $\mathrm{P}$, Offner $\mathrm{M}$. A new method for determination of oxalate in blood serum by gas chromatography. Clin Chim Acta 1978; 82: 9-12.

10 Knowles CF, Hodgkinson A. Automated enzymic determination of oxalic acid in human serum. Analyst 1972; 97: 474-481.

11 Bennett DJ, Cole FE. Frohlich ED. Erwin DT. A radioenzymatic isotope-dilution assay for oxalate in serum or plasma. Clin Chem 1979; 25: 1810-1813.

12 Wolthers BG, Hayer M. The determination of oxalic acid in plasma and urine by means of capillary gas chromatography. Clin Chim Acta 1982; 120: 87-102.

13 Akcay T, Rose GA. The real and apparent plasma oxalate. Clin Chim Acta 1980: 101: 305-311.

14 Williams HE, Johnson GA. Smith LH Jr. The renal clearance of oxalate in normal subjects and patients with primary hyperoxaluria. Clin Sci 1971: 41:213-218.

15 Pinto B. Crespí G. Solc-Balcclls F, Barccló P. Patterns of oxalatc metabolism in rccurrent oxalate stone formers. Kidney Intern 1974; 5: 285-291.

16 Hodgkinson A, Wilkinson R. Plasma oxalate concentration and renal excretion of oxalate in man. Clin Sci Mol Med 1974; 46: 61-73.

17 Prenen JAC, Boer P, Dorhout Mees EJ, Endeman HJ, Spoor SM. Oei HY. Renal clearance of $\left[{ }^{14}\right.$ C]oxalate: comparison of constant-infusion with single-injection techniques. Clin Sci 1982: 63: 47-51.

18 Constable AR, Joekes AM, Kasidas P, O'Regan P, Rose GA. Plasma level and renal clearance of oxalate in normal subjects and in patients with primary hyperoxaluria or chronic renal failure or both. Clin Sci 1979; $56: 299-304$.

19 Kohlbecker G, Richter L, Butz M. Determination of oxalate in urine using oxalate oxidase: comparison with oxalate decarboxylase. J Clin Chem Biochem 1979; 17: 309-313.

20 Chiriboga J. Purification and properties of oxalic acid oxidase, Arch Biochem Biophys 1966; 116: $516-523$.

21 Bergmeyer HU. Methoden der Enzymatische Analyse, 2nd Ed, Weinheim: Verlag Chemie, 1970: $455-456$.

22 Elder TD, Wijngaarden JB. The biosynthesis and turnover of oxalate in normal and hypcroxaluric subjects. J Clin Invest 1960; 39: 1337-1344. 